\title{
Coulisses
}

Revue de théâtre

25| Hiver 2002

Varia

\section{Les formations traditionnelles théâtre}

\section{Françoise Quillet}

\section{OpenEdition}

Journals

Édition électronique

URL : http://journals.openedition.org/coulisses/6048

DOI : $10.4000 /$ coulisses. 6048

ISSN : 2546-9460

\section{Éditeur}

Presses universitaires de Franche-Comté

\section{Édition imprimée}

Date de publication : 1 janvier 2002

Pagination : 107

ISBN : 2-84627-052-X

ISSN : $1150-594 \mathrm{X}$

\section{Référence électronique}

Françoise Quillet, «Les formations traditionnelles théâtre », Coulisses [En ligne], 25 | Hiver 2002, mis en ligne le 24 octobre 2019, consulté le 15 novembre 2019. URL : http://journals.openedition.org/ coulisses/6048; DOI : 10.4000/coulisses.6048

Ce document a été généré automatiquement le 15 novembre 2019.

Coulisses 


\title{
Les formations traditionnelles théâtre
}

\author{
Françoise Quillet
}

1 Le DEUG ARTS mention Arts du spectacle (spécialité théâtre) a été créé en 1996 à l'université de Franche-Comté, lui ont fait suite en 2000 la licence et en 2001 la maîtrise.

2 Ces deux cycles comprennent les enseignements propres à toute formation universitaire concernant le théâtre et des enseignements spécifiques à l'université de Franche-Comté :

- ateliers d'écritures théâtrales, dirigés en maîtrise par Michel Azama en 2002

- étude des théâtres africains, américains, asiatiques, brésiliens, hispano-américains

Des artistes de ces divers pays sont invités à venir faire des conférencesdémonstrations aux étudiants

- cours théoriques et ateliers pratiques concernant la musique, la danse et leurs rapports au théâtre (intervention de la compagnie Schmid-Pernette et d'Odile Duboc, directrice du Centre chorégraphique de Belfort)

4 Le rapport du théâtre contemporain à la musique et à la danse, fait partie d'un domaine de recherche en plein développement dans les études théâtrales, c'est pourquoi les artistes-chercheurs et les enseignants-chercheurs travaillant dans ce domaine à l'université de Franche-Comté, se sont donnés comme tâche de publier régulièrement leurs recherches en ce domaine, le premier ouvrage verra le jour en 2003. 


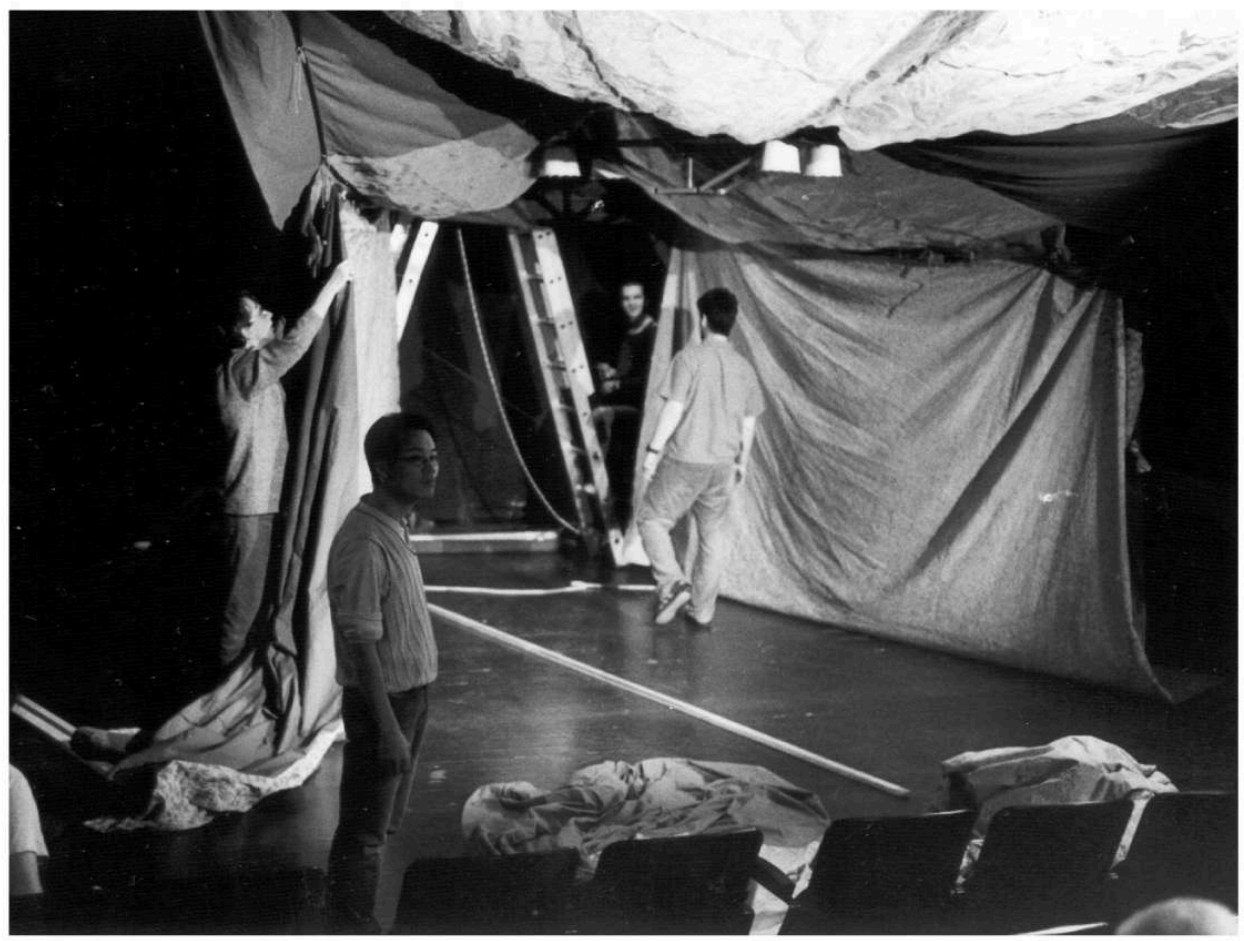

Cliché TUFC 